\title{
Mitigating the Socio-Economic Impacts of COVID-19; Role of Governments in Sub-Saharan Africa, Fiscal and Monetary Policy Perspectives
}

\author{
Elijah Asante Boakye ${ }^{1,2 *}$, Hongjiang Zhao1,2, Bright Nana Kwame Ahia',2, Millicent Adu Damoah ${ }^{1,2}$ \\ ${ }^{1}$ School of Management and Economics, University of Electronic Science and Technology of China, Chengdu, China \\ ${ }^{2}$ Center of West African Studies, University of Electronic Science and Technology of China, Chengdu, China \\ Email: ^el.asante2@yahoo.com, zhaohj@uestc.edu.cn,obrempong0673@gmail.com, millie13392@gmail.com
}

How to cite this paper: Boakye, E. A., Zhao, H. J., Ahia, B. N. K., \& Damoah, M. A. (2020). Mitigating the Socio-Economic Impacts of COVID-19; Role of Governments in Sub-Saharan Africa, Fiscal and Monetary Policy Perspectives. Open Journal of Social Sciences, 8, 300-318.

https://doi.org/10.4236/jss.2020.811028

Received: July 26, 2020

Accepted: November 24, 2020

Published: November 27, 2020

Copyright $\odot 2020$ by author(s) and Scientific Research Publishing Inc. This work is licensed under the Creative Commons Attribution International License (CC BY 4.0).

http://creativecommons.org/licenses/by/4.0/

\begin{abstract}
In this paper, we investigate the role of governments in mitigating the socio-economic impacts of COVID-19. We also try to evaluate the fiscal and monetary policy interventions by governments and assess how such policies could be sustained. Taking Ghana as a sample, this study reveals that, the coordinated applications of monetary and fiscal policies are lifesaving, preventing loss of incomes and jobs, protecting bankruptcies in businesses, and finally enhancing economic recovery. We propose a CCCRD Model which could serve as a global strategy for governments in the fight against COVID-19. Backing such policies with legislation could help in their sustenance.
\end{abstract}

\section{Keywords}

COVID-19, Sub-Saharan Africa, Fiscal \& Monetary Policy, Socio-Economic Impact

\section{Introduction}

Regardless of the significant therapeutic breakthroughs over decades, many contagious diseases like malaria, common cold, meningitis, influenza still plague society and present an enormous threat to human life. As some are native to geographically specified regions, others turn into epidemics by affecting a lot of people at the same time, with few spreading beyond such boundaries into becoming pandemics. With the loss of human life being the critical aspect of infectious diseases, their spread can also have significant regional and national economic implications (Delivorias \& Scholz, 2020). Prior studies focusing on this aspect of pandemics have found significant effects across economies, thus through 
several sectors like agriculture, healthcare, sports, transportation, tourism, and international trade (Kostova et al., 2019).

The World Bank (WB) and World Health Organization (WHO), jointly reported an estimated rise in the total cost of GDP globally from $2.2 \%-4.8 \%$ to be (US\$ 3 trillion) as a result of the effects of the COVID-19 pandemic. It was further reported that the GDP's in Sub-Saharan Africa and South Asia could decline by $1.7 \%$ (US\$ 28 billion) and 2\% (US\$ 53 billion) respectively (Rummo \& Soosaar, 1998). The COVID-19 pandemic is testing societal and economic limits globally and Sub-Saharan Africa is more likely to be hit hard. This is a result of more vulnerable and poor populations, inadequate savings to care for financial calamities, limited access to health care, and weaker health systems. The outbreak of COVID-19 is anticipated to lead Sub-Saharan Africa into recession (World Bank, 2020) and world donors are making available emergency funds to fight and mollify its socio-economic impacts.

In the midst of these, several initiatives like fiscal, monetary, and non-monetary policies have been implemented by governments globally to redeem their economies from such repercussions. There have been growing demands that governments will have to help businesses that are losing income and going bankrupt, financial institutions that are suffering knockdown effects, and the economy at large (Hossain \& Green, 2012). Despite the restrictions on people and interruption to supply chains, fundamental goods and services must be provided, and incomes and employment should be essentially maintained. Given the above, this study posits to address the socio-economic impacts of COVID-19 across Sub-Saharan Africa? Secondly, we evaluate how governments' fiscal and monetary policy interventions can help in mitigating the COVID-19 effects? Due to the uncertainties surrounding the COVID-19, we lastly, assess how such interventions could be sustained as long as the pandemic travels over time.

This will bring into light the commitment of governments in providing and sustaining the basic interventions such as good healthcare systems, set up funds for unforeseen future pandemics, and subsidies for businesses. Using Ghana as a sample, this study addresses the socio-economic impact of COVID-19, on key areas like social life, education, public gathering; indicators like agriculture, hospitality, foreign direct investment, trade, and industry. We also explore and evaluate the fiscal and monetary policy interventions employed by the government of Ghana in mitigating the impact of the pandemic. The paper is arranged in this order: Section 1, considers the introduction, followed by Section 2 which reviews related literature. Then Section 3 presents the methodological approach with Section 4 later discussing the findings and Section 5 with conclusions of the paper.

\section{Literature Review}

\subsection{Epidemiology of COVID-19}

Coronaviruses are a part of the Coronaviridae group under the Nidovirales 
structure that could be transmitted among animals and humans as well. The virus's outlying crown-like pins led to the origination of the name coronavirus (Shereen, Khan, Kazmi, Bashir, \& Siddique, 2020). Their miniature disposition contains a nucleic material with one-stranded RNA having between 26 - $32 \mathrm{kbs}$ in length. The subgroupings of coronaviruses include the H5N1 influenza A, H1N1 2009, Middle East respiratory syndrome coronavirus (MERS-CoV), and severe acute respiratory syndrome coronavirus (SARS-CoV). Coronaviruses were only known to infect animals just before the world experienced a severe acute respiratory syndrome (SARS) outbreak in 2002 (Zhong et al., 2003). The severity of coronaviruses can progress into acute respiratory distress syndromes, sepsis, septic shock, and serious pneumonia which may cause death (Alexandria et al., 2016).

The Corona Virus Disease 2019 (COVID-19) is described as a contagious disease which is caused by severe acute respiratory syndrome coronavirus 2 (SARS-CoV-2) (Zimmermann \& Curtis, 2020). This new strain of the virus which had not been formerly known to live in humans breaks out in the city of Wuhan (Hubei Province) in China. With sputum production, shortness of breath, and cough as its non-specific symptoms, the main medium of spread is through respiratory droplets. COVID-19 has an estimated incubation period of 2 - 14 days with no current vaccine to forestall its threats. Additionally, no conclusions have been reached in finding a cure as much its nature and dynamics are still unknown. The World Health Organization (WHO), in January 2020 declared a public health emergency globally (WHO, 2020). With the situation increasing rapidly, COVID-19 has led to an upsurge in the number of severe pneumonia cases, including America, Europe, and Africa. The World Health Organization (WHO) reports a total of 47,894,604 cases with 88,174 in severe conditions. As of $4^{\text {th }}$ November 2020, COVID-19 had claimed 1,221,340 lives and is affecting 214 countries and territories. With a fatality rate of $\sim 3.4 \%$ and a transmission rate of 2 - 3 newly infected from 1 case, the United States of America, India, Brazil, Russia, and France are the top five countries with total confirmed cases and as against a total worldwide recovery of 33,899,852 (COVID-19 Statistics, 2020).

\subsection{Socio-Economic Impact of COVID-19}

The basic impact of COVID-19 is seen in the health sector with a substantial number of deaths and infected patients. This has overstretched the capability of many hospitals globally in terms of resources and personnel thus alerting governments to provide the necessary support to augment the efforts of the health sector. Regardless of the effect of COVID-19 on the health sector, it has promulgated the ripple effects on almost every aspect of the global economy, thus from industries that extract raw materials (primary sector), through to the ones that transform raw materials into finished products (secondary sector) and finally to the industries that provide services to its consumers (tertiary sector) 
(Nicola et al., 2020).

\subsubsection{Social Impact of COVID-19}

With lockdowns, social distancing, and a ban on public gatherings being implemented globally to mitigate the spread of COVID-19, this has affected the social fabric of society and disrupted the way of life. There have been heightened concerns for both physical and emotional trauma due to these measures as families, friends, and other relatives are unable to meet as usual to share love and care. Other activities like sports which sort to bring joy and happiness to people have all been postponed due to this pandemic with notable ones like the Euro 2020 tournament, the Australian Formula One Grand Prix, the Tokyo 2020 International Olympic Games. Other examples such as basketball, athletics, rugby, tennis cycling, soccer, boxing, and golf have all been suspended to limit the COVID-19 spread (Uefa, 2020). The UN Department of Economic and Social Affairs (UN DESA) reported the impact of COVID-19 as being very destructive to older, poor, youth, indigenous, and persons with disabilities. These social groups of people are likely to suffer unfairly from the pandemic and its post-effects, leading to higher levels of inequality, xenophobia, and unemployment globally (United Nations, 2020).

\subsubsection{Economic Impact of COVID-19}

The COVID-19 pandemic is still plaguing the world and ripping it off economic gains. With shutdowns and lockdowns domineering the measures being taken to limit the spread of the virus, this has impacted business activities right from the primary sector to the tertiary sector industries. According to $\mathrm{S} \& \mathrm{P}$ ratings, COVID-19 is estimated to cause the global GDP baseline growth rate for 2020 to decline by 0.3 percentage point (ppt); Asia-Pacific by $0.5 \mathrm{ppt}$; China by $0.7 \mathrm{ppt}$; Europe and USA by 0.1 to $0.2 \mathrm{ppt}$ ( $\mathrm{S} \& \mathrm{P}$ Global, 2020). The primary sector which refers to business units that are involved in the extraction of raw materials like agriculture and mining of minerals and oils have not been spared. On the agriculture front, the cultivation of crops and rearing of animals has been disrupted since farmers are being asked to stay home. The ripple effect may include shortages of food crops which could lead to famine if unchecked, unemployment, and foreign exchange decline for countries that largely depend on the exportation of agriculture and mining products. With workers being asked to stay home and companies being shut down, productivity is been greatly hindered. In the mining of minerals and oil extraction, COVID-19 has significantly caused a drop in oil demand.

This is a result of the decline in demand of $25 \%$ by China which had over the past years been the country with the highest demand for world oil. The demand by China fell due to the quarantined measures which lead to the shutdowns of many businesses (World Bank, 2020). Similarly, due to the COVID-19 pandemic, Saudi Arabia's response led to the announcement of a discount in oil prices and this led to a more than 1000 points drop in Dow futures. Additionally, S \& P 
500 futures also plunged by $5 \%$, and a record low of the 10 -year Treasury Note Yield falling under 0.5\% (Schneider \& Domonoske, 2020). From the secondary sectors, the issues have not been different anyway. With workers being asked to stay home and observe social distancing, the transformation of raw material into finished products has also been impacted. This has also disrupted supply chains, causing delays in business operations and increased unemployment. Subsequently, this has limited the flow of goods and services, movement of people, slowing down economies and is gradually leading into global recession. This has led to much higher economic costs leaving unknown, the multiple dynamics of the COVID-19 crisis (Szlezak, Reeves, \& Swartz, 2020). Additionally, with several months of lockdowns and social distancing, growth in productivity declines as a result of the limit on the formation of capital and labor output, pushing the economy into bankruptcy.

The tertiary sector which is predominated by industries like hospitality, aviation, education, and entertainment has also been greatly impacted by the COVID-19. France, Greece, and Italy are an example of economies that could be greatly affected and hence will need to adjust their annual forecasts since they depend highly on tourism (Delivorias \& Scholz, 2020). COVID-19 has also uncommonly extended challenges to the real economy, capital, and liquidity structure. In the financial system, COVID-19 shocks have duly caused capital market stress, sparking central banks to employ cogent measures to salvage the situation (Szlezak et al., 2020). The transportation sector especially aviation has also been kept in the dark. With most airports been shut down globally and airlines not operational, has immensely disrupted the supply chains as well as travels for tourism or other business-related purposes.

Airports are estimated for over US\$ 76 billion loss in revenues in 2020 as compared with their normal business operations in 2019. Subsequently, the revenues of airlines are anticipated to decline by 48\% (ICAO, 2020). COVID-19 has also affected the education sector with the closure of schools in an attempt to curb the spread of the virus and has negatively affected the quality of teaching and learning. With the closure of these institutions, entities that hold direct and indirect business ties with them are all being pushed out of business thus creating unemployment. An estimate of about 900 million students has been made to stay home (UNESCO, 2020), as the COVID-19 continues to affect the globe. Governments and other stakeholders have implemented public health and safety measures to palpably rattle the spread of infection.

\subsection{Sub-Saharan African in Perspective}

With weak health systems and vulnerable populations, the COVID-19 is already making a greater socio-economic impact. For the first time in 25 years, the COVID-19 impact is likely to push Sub-Saharan Africa into a great recession. The African Union has reported a total of $1,813,065$ cases as of $4^{\text {th }}$ November 2020 with 43,612 deaths and 1,484,042 recoveries (Africa CDC, 2020). With a 
negative growth rate of $5.1 \%$, this pandemic is estimated to cost output losses between US\$ 37 billion and US\$ 79 billion due to supply chain and trade interruptions, driving millions into hardships (The World Bank, 2020a). In Angola, South Africa, and Nigeria, which are the three largest economies, growth in real GDP is estimated to decline sharply. Countries that export oil will also be hard hit and this is expected to considerably cripple growth in the East African Community and West African Economic and Monetary Union.

This would be a result of a decline in local production, foreign demand as well as supply chain disruptions. Unemployment will also not be spared as about 259 million Africans in the informal urban sector are likely to be affected. Subsequently, SME's that provide about $80 \%$ employment in Sub-Saharan Africa are highly susceptible to the COVID-19 and its related effects. With the spread of COVID-19 across the continent, agricultural production is forecasted to shrink from $2.6 \%$ to $7 \%$ leading to a crisis in food security. These effects promulgate into higher costs of living due to the reportage of approximately $100 \%$ upsurge in the prices of some goods and services (ECA, 2020). In the event of mitigating the COVID-19 impact on Sub-Saharan Africa, the world bank has made calls to bilateral creditors including the United States of America and China to hold on with the payment of debts by the poverty-stricken countries temporarily so that such funds can be used to curb the transmission of the virus and alleviate its financial-related impact.

This will lead to sustaining the macroeconomic stability of the region (The World Bank, 2020b). The social impacts can also not be undermined with lockdowns, travel bans, and social distancing being key litigating measures towards the spread. The educational system, family dynamics, entertainment, and sporting activities, social gatherings such as churches, mosques, funerals have all been put on hold temporarily, thus affecting the very fabric that holds the society together.

\subsection{Role of Governments}

The focus of governments across the globe has recently shifted to protecting lives through expenditures to bolster health systems and agile actions to reduce economic activity disruptions. These actions although different across countries have some key dominating ones like lockdowns, social distancing, travel bans, shutdowns, and personal hygiene. The alarming rate of spread of the COVID-19 globally is propelling governments to act distinctively to avert its threats to human life and the economy. As a result of the uncertain timeline for the development of a vaccine, governments are undertaking all-out measures (Eggers et al., 2020) to primarily deal with the critical economic and medical challenges and their related effects. Monetary, fiscal, and non-monetary policies are being implemented to make flat the spread curve and enhance capabilities where needed.

The examples of non-monetary policy interventions include but not limited to social distancing, testing the masses, travel bans, providing digital tools for con- 
tract tracing and surveillance, use of communication platforms to inform and educate people, lockdowns, providing incentives for the diagnosis and development of vaccines (John, 2020; King, 2020).

Assessing the interventions of governments and the World Health Organization (WHO) recommendations, we propose a CCCMD Mitigation Model which could be a global strategy that could be employed by governments in the fight against the COVID-19. Coordinate the efforts of all public and private agencies towards the education of people on preventive measures such as personal hygiene, social distancing, and practicing good respiratory manners. Control the local spread by regulating public gathering. It also includes appropriate infection detection through contact tracing, surveillance, and quarantining suspected persons where adequate healthcare could be provided.

Contain the local spread by instituting measures on the movement of people, social distancing, and adequate travel restrictions on non-essential travels both domestically and internationally. Minimize the mortality rates through the provision of continued healthcare services to affected patients whilst protecting unsafe populations and healthcare workers on the frontline. Develop effective therapeutics and safe vaccines for extensive delivery and easy accessibility (Figure $1)$.

\subsubsection{Global Interventions}

Recently, most governments have hinted at significant programs to provide economic and social respite on both a short-term and long-term basis. In the United States of America, relief funds of US\$ 1200 were made available to citizens with less than US\$75,000 or US\$150,000 for couples (U.S. Department of Labor, 2020). Additionally, US\$25 billion and US\$ 100 billion worth of assistance have been made for food and healthcare respectively. Subsequently, a total of US\$ 377 billion has been set up to provide grants and loans for small scale businesses with compensation for the unemployed being increased by US\$ 600 per week (Deloitte Insights, 2020). Also, the South Korean government made cash payments of US\$ 820 for all families outside the country's top 30\% income earners totaling US\$ 7.44 billion. Another US $\$ 5.80$ billion was made available to augment the activities of small and medium-sized enterprises (Nikkei Asian Review, 2020).

Subsequently, the Chinese and Japanese governments took akin actions by

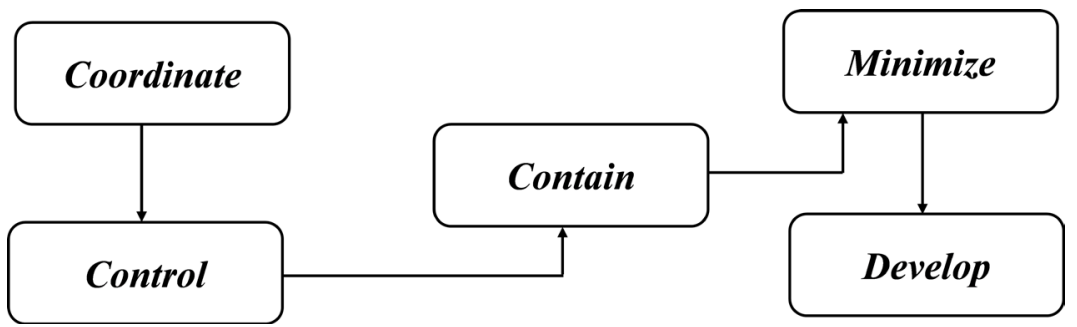

Source: Authors.

Figure 1. CCCMD mitigation model. 
allowing for cash equivalents of US\$240 billion and US\$ 43 billion respectively to maintain and boost liquidity in the banking sector (The Straits Times, 2020; Deloitte Insights, 2020). This forms part of the efforts of governments in maintaining stability in the financial systems to mitigate the impact of COVID-19. In Europe, the case has not been any different as the European Central Bank (ECB) dedicated a $€ 750$ billion for an asset-purchase initiative in anticipation to strengthen and sustain the Euro as the pandemic still plague its member countries. In furtherance, the European Commission has softened budget policies to help affected firms and boost public expenditure (Tobias Buck et al., 2020)

In Sub-Saharan Africa, the majority of the mitigating measures are through executive orders. Currently, a state of emergencies has been declared across 28 countries. However, with an upsurge in the number of recorded cases in South Africa, Zimbabwe, and Malawi, their governments have declared states of national disaster. Ban on public gatherings, social distancing, closure of airports and borders, and the imposition of curfews have dominated the measures of mitigation to curb the spread of the coronavirus. With 37 countries fully locking down or partially banning public gatherings and imposing curfews, religious activities, schools, social and other family-related activities have all been negatively impacted (ICNL, 2020).

\subsubsection{Adversities from Government Interventions}

Regardless of the government's goal to protect lives and put their economies back into shape, their several fiscal, monetary, and non-monetary interventions have brought some discomfort to the lives of people and disrupting the very fabric that holds the society together. With the ban on public gatherings, lockdowns, social distancing, quarantining, compulsory wearing of nose masks, and closure of public places have been critical. (Singh et al., 2020) report that lockdowns create anxiety and fear across the globe, having long-term mental health and psychosocial denotations especially for adolescents and children. There is a greater impact on the social and emotional development of younger children and adolescents than adults. Additionally, the closures of colleges and schools nationwide negatively impacts more than $91 \%$ of the student population worldwide (Lee, 2020), with confinement at homes increasing anxiety and uncertainty which could lead to interruptions in their physical activities, opportunities for socialization, and education (Jiao et al., 2020) which in the end affects human capital development for the society.

With lockdowns in developing countries, the less privileged face acute nutrition deprivation and protection with its prolongment leading to loss of income, exposing children especially to a higher risk of facing abuse and unfavorable economic (Dalton, Rapa, \& Stein, 2020). (Fana, Tolan, Torrejón, Urzi Brancati, \& Fernández-Macías, 2020) report that temporary and self-employed workers are more likely to be impacted by the social distancing measures and would be put out of work. With the unemployment rates soaring due to this income levels are affected and this disrupts the care for the family as basic needs might not be 
provided for by the affected employees. The increased poverty and inequality levels distort the family structure and society at large.

Additionally, lockdowns have placed many businesses out of work causing higher labor market inequalities especially for men and younger workers (Béland, Brodeur, \& Wright, 2020). With shutdowns, businesses that provided auxiliary services to keep the society running are negatively affected, disrupting the normal flow of activities across societies. The ban on social activities and public gathering has not only rendered people bored, it has caused so much stress, anxiety, taking away the joy and happiness that people normally enjoy in such at such euphoria's. The social setting of societies are impacted as people now tend to live in isolation devoid of gatherings to share love, spend time with family and friends (United Nations, 2020) with people not able to meet.

\subsection{Theoretical Perspectives}

This study considers these theories as relevant in achieving the research objectives as they serve the basis for our assumptions about the phenomenon by which the underlying results can be achieved.

\subsubsection{Monetary Policy}

Governments through their respective central banks normally use monetary policies to stimulate and drive economic activities. This is achieved by its ability to encourage individuals, households, and firms to spend and borrow. With the related effects of COVID-19 on the savings and expenditure of households, businesses, and governments, we argue the use of monetary policies to stimulate the economy. With the loss of jobs and inflation as being other forms of the effect of this pandemic due to lockdowns and shutdowns, governments could either increase or decrease the supply of money to influence the rates of inflation and growth. Monetary policies could be initiated to lower the borrowing costs to support businesses from going bankrupt and collapsing due to COVID-19 and also bolster the spending of consumers due to unemployment and lockdowns with lower rates of interest.

\subsubsection{Fiscal Policy}

Governments' two main ways of implementing fiscal policy are through the changes in tax and expenditure policies. In situations where there are not enough economic activities over a given period, governments could initiate stimulus packages to increase their expenditure or simply inject money into the economy. Against the COVID-19 pandemic, we argue that governments could undertake a variety of fiscal policy initiatives such as giving stimulus packages to businesses to support their operations, payments to the vulnerable and unemployed, tax waivers, and so on.

\subsubsection{Decision Theory}

Fundamentally resides on the concepts and techniques that support decision-makers in handling complicated decision problems under uncertain future 
outcomes. With governments taking appropriate COVID-19 mitigating measures, they will need to evaluate the options available and select the appropriate initiative which provides the best results. Against this, we contend that the ability of governments to properly evaluate alternatives available under uncertain future results provides the basis to make the best decisions to obtain the right results.

\subsubsection{Sustainability Theory}

With the uncertainties surrounding the development of a vaccine for the COVID-19, governments must be concerned about how long their initiatives could be maintained over a given period as long as the pandemic travels. This theory considers the long-term viability of government interventions and how long they can feasibly travel without being diminished over time. Against this background, governments need to consider how sustained their initiatives could be before implementations.

\section{Methodology}

\subsection{Study Design}

The study's design is purely exploratory as it employed the use of numerous articles, journals, and online reports to observe and understand the COVID-19 pandemic. We also explore the socio-economic impact of COVID-19 to create awareness and also evaluate the mitigation interventions being deployed by governments.

\subsection{Data Source}

The case of Ghana is specifically considered for this study. Secondary data on the COVID-19 pandemic were used from various articles, journals, and other research papers from a variety of sources like World Health Organization (WHO), World Bank, UNESCO as well as other media platforms like ICNL, Africa Pulse, Reuters, Africa news to better report on the socio-economic impact of COVID-19 and discuss the fiscal and monetary policy interventions being employed to mitigate such impact.

\subsection{Case Selection}

Ghana which is one of the fast-developing countries in Sub-Saharan Africa was amongst the earliest countries to record COVID-19 on its shores. Currently, it is also one of the countries with the highest testing, surveillance, and contract tracing capacity. Due to the country's sustained growth and development, the World Bank is providing US\$ 100 million in the form of short, medium, and long-term assistance to augment the country's effort to tackle the COVID-19 pandemic. This package consists of emergence supports with US\$ 35 million to assist the country in the provision of enhanced response systems. This support will offer the Government of Ghana the ability to detect, respond, and prevent the 
pandemic through the Ghana Emergency Preparedness and Response Project (EPRP).

The EPRP is set to assist in boosting Ghana's National Laboratories by enhancing a robust structure for the initial detection, real-time surveillance of disease, and outbreak reporting systems (The World Bank, 2020c). Regardless of the supports from World Bank, the Government of Ghana has also initiated some fiscal and monetary policy interventions and these include a GH $\not 600$ million loan disbursement for small and medium scale enterprises, recruitment of 1000 volunteers into the health sector, defer payments of interest on non-marketable instruments until 2022, 1.5\% decrease in policy rates, the establishment of coronavirus alleviation program, $\mathrm{GH} \notin 3$ billion to support industries especially the pharmaceutical, hospitality, service, and manufacturing, absorbed water bills for all Ghanaians until end of June. It is against these backgrounds that this study is carried to assess the socio-economic impact of COVID-19 as well as evaluate both the fiscal and monetary policy interventions and finally report on the sustainability of such interventions as the fight still lags on.

\section{Findings}

\subsection{Socio Impact of COVID-19 on Ghanaians}

The social lives of Ghanaians like all other persons globally have not to be spared by the emergence of COVID-19. In governments' response to mitigate the spread, several interventions have been taken and these have taken tolls on the very facet of life that holds people and the society together. In Ghana, there have been bans on all public and social gatherings including conferences, schools, workshops, sports, festivals, religious activities, funerals, political activities to limit the transmission of COVID-19. In the area of education, all schools have been temporarily closed down throughout the entire country until further notice. The West African Secondary School Certificate Examinations (WASSCE) and Basic Education Certificate Examinations have both been suspended across participating West African Anglophone countries for which Ghana is a member (Rossiter \& Abreh, 2020).

Aside from keeping students and teachers at home, it has created unemployment for persons who provide auxiliary services for the education sector. Regardless of this, governments and other stakeholders have taken measures to sustain teaching and learning through virtual platforms. The ban on social gatherings is making it very unbearable for the day to day personal movement and way of life of people hence disrupting the social order temporarily (Nyabor, 2020).

\subsection{Economic Impact of COVID-19 on the Ghanaian Economy}

\subsubsection{Agriculture}

The impact of COVID-19 on agriculture may not be very stern at the initial stage. This is because agriculture in Ghana does not rely significantly on the 
importation of transitional products. However, the growth rate could be staggered due to supply chain disruptions, lockdowns, limited access to farm inputs like fertilizers, insecticides, and seeds for planting. Additionally, planting decisions could be negatively affected as crops that could have been propagated within the lockdown period could no longer be done. As the duration of the lockdown continues, there will be a decline in the cultivation of food crops for both local consumption and exports. These contractions could impact the overall economic activities (growth rates of GDP) and higher rates of unemployment as agriculture contributes to about $20 \%$ of GDP and employs a larger workforce of the population (Ministry of Business Development, 2017). The estimated GDP growth for the Ghanaian economy will decline to about $2.6 \%$ in 2020 from an initial target of $6.8 \%$ (Deloitte Ghana, 2020).

With the pandemic being intensified, shocks would be exerted on demand for final foods, a more rapid increase in unemployment levels (Josef Schmidhuber et al., 2020). The intensity of the effects on demand for food will rely on many factors which may include the extent of macroeconomic shock, credit facility access, and the savings available. In worst situations, there could be food shortages, and this will to a larger extent cause inflation in the prices of food products especially rice, vegetables, meat, and other poultry products (Ministry of Finance, 2020).

\subsubsection{Hospitality}

The hospitality industry has been negatively impacted globally and that of Ghana is no exception. With flight cancellations, border and airport closures (sea, air, and land), social distancing measures, and the ban on public gatherings have badly affected the operations of the hospitality sector. Among these are the hardest hit ones like aviation, hotels, restaurants, tourist, and amusement sites. The occupancy rates of hotels have declined due to a steep fall in bookings to less than $30 \%$, thus causing some increased rates of unemployment to hotel staff and other units that provide augmented services for them. Some high-profile international conferences like the $4^{\text {th }}$ African Union Specialized Technical Committee (STC) on Finance and the G24 Technical meetings, scheduled in March have all be canceled, which could have boosted the hospitality industry in Ghana (Ministry of Finance, 2020).

Additionally, the travel bans and closure of airports have delayed a lot of business transactions and limited the flow of funds and goods which often sustained local families. Ghana's Aviation which is very delicate to international trade, business, and tourism has been negatively impacted. With notable airlines like Delta, Emirates, and KLM suspending flights into the country, it is estimated that revenue for the Ghana Aviation Industry will decline by $20 \%$. In 2018, the Ghana Airport Company reported total revenue from taxes alone at the airport to be GH $\notin 475.56$ million (Ministry of Finance, 2020).

However, this increased more than about 35\% in 2019, but with the current stage of the COVID-19, it is very unlikely to meet such levels in the 2020 finan- 
cial year. Import duties are also estimated to decline by $\mathrm{GH} \not 808$ million (Ministry of Finance, 2020). This could also be a result of the reduction in airport taxes, landing, and airspace charges on passenger safety. Additionally, employees in the aviation industry such as servicing aircraft, air traffic controllers, airport securities, immigration and customs, management of airports, ground handlers, and so on are all at risk of losing their jobs (Ayetey, 2020).

\subsubsection{Trade and Industry}

Trade volumes and values (both domestic and international) are also reducing as a result of the COVID-19 pandemic. The Ghanaian economy is already seeing significant reductions in trade volumes and values with its trade partners, especially China, which constitutes the highest of Ghana's imports and the second-highest of Ghana's exports. Total international trade volumes for both imports and exports increased respectively from US\$13,134 million (2018) to US\$13,411 million (2019) and US\$14,943 million to US\$ 15,668 million (The World Bank Group, 2020b). However, both the exports and imports for goods and services are estimated to decline by $-2.3 \%$ with a forecast of $-3.2 \%$ for exports and $-3.0 \%$ for imports (African Economic Outlook, 2020). Observing the reduced arrival of containers at the ports by at least a third has caused a decline in import duties. Reductions in imported intermediate goods could significantly slow down manufacturing activities in Ghana. Reductions in imports of goods and services are, however, expected to reduce the demand for forex and the importation of goods and services. This has a favorable impact on foreign exchange volatility and the country's net international reserves.

\subsubsection{Foreign Direct Investment (FDI)}

The outlined Foreign Direct Investment (FDI) in 2020 has slackened as a result of the COVID-19 pandemic. The travel bans and lockdowns have both limited foreign business meetings and deals from being fruitful. With shutdowns likely to emanate, firms that depend on foreign investments will experience contractions due to the uncertainties surrounding the pandemic which could pose some financial constraints on their activities. Subsequently, foreign investors being unable to visit Ghana to transact business dealings could hamper the country's estimated FDI. The net inflows of FDI were US\$ 2.989 billion and US $\$ 2.319$ billion for 2018 and 2019 respectively (The World Bank Group, 2020a), however, the influence of the COVID-19 pandemic has caused a decline to US\$785.62 million between January to June 2020 (Ghana Investment Promotion Centre, 2020). The global nature of COVID-19 is also affecting countries like China, India, United Kingdom, and France (Santander Group, 2020), which have huge investments in Ghana as they are also battling with the pandemic hence their investments could shrink. With Mining and oil exploration being the main sectors of FDI, shutdowns and lockdowns have disrupted their operations hence their revenue. This is a larger extent will affect the subsequent decisions by investors. 


\subsection{Fiscal \& Monetary Policy Mitigations by the Government of Ghana}

Good monetary policies have been enabling governments to regulate their fiscal policies in supporting the economy, by making funds handy for businesses, employees, and families during the COVID-19 pandemic. Monetary policy tools continuously assuage both the financial and liquidity constraints to support countries with the needed fiscal capacity to help economic activities. Governments globally have implemented a lot of mitigating measures to counter the spread and disruptions created by COVID-19, Ghana through the Ministry of Finance, which has already employed some measures and still looking forward to implementing a combination of monetary and fiscal measures in mitigating the socio-economic impacts of COVID-19. The key ones include the following:

- The setting up of a Coronavirus Alleviation Programme (CAP) with GH $\varnothing$ 1.25 million to expedite recovery for the economy.

- Arranging with the Bank of Ghana (BoG) to defer the payments of interests on non-marketable instruments which are estimated at $\mathrm{GH} \varnothing 1.3$ million.

- Establishing a syndication facility of GHф 3 billion to support the hospitality, service pharmaceutical, and manufacturing sectors.

- Amending the Petroleum Revenue Management Act (PRMA) to pave way for withdrawals to fund COVID-19 pandemic urgent expenses; from the Ghana Heritage Fund which has an estimated US\$ 591.1 million.

- Adjusting all expenses on Capex, services, and goods downwards by $\mathrm{GH} \not$ 1.24 million.

- Reducing policy rate to $14 \%$ by 150 basis points and reducing the regulatory reserve requirement to $8 \%$ from $10 \%$ to boost the credit supply for the private sector.

- The lowering Ghana Stabilization Fund (GSF) cap to US\$100 million from the current US\$ 300 million to facilitate excess fund transfers into the CAP.

- Setting up GH\& 600 million loan disbursement for small and medium scale enterprises.

- Paying GH\& 300 million to the National Health Insurance Authority (NHIA) as part of measures to provide liquidity to the pharmaceutical sector and Health Care providers. Additionally, the Government has arranged for Life and Sickness Insurance for COVID-19 pandemic frontline health workers.

- Reduction of interest rates priced-off the Ghana Reference Rate (GRR) by 200 basis points which are (2\% per annum).

The implications of these interventions cannot be undermined as they have created a certain level of ease for individuals, households, and businesses. The coordinated and promptly application of both monetary and fiscal policies has been lifesaving, preventing loss of incomes and jobs, protecting bankruptcies in businesses, and finally enhancing economic recovery. Sustaining the operations of small and medium scale enterprises has been very key in putting the economy back into shape. Additionally, the establishment of the CAP is enormously en- 
hancing the contact tracing, surveillance, testing, and quarantining and this is also very important in fighting the spread of COVID-19. The provision of liquidity to pharmaceutical companies and insurance packages for frontline workers has also been of great benefit with companies embarking on needed research on therapeutics and diagnostics whilst frontline health workers are duly motivated to give their best efforts.

\subsection{Sustainability of Fiscal \& Monetary Policy interventions}

Sustaining the mitigating measures against COVID-19 is very important. However, due to the uncertainties surrounding the pandemic as in the area of vaccine development, it has become more crucial as to how long such policies can be held on and even post COVID-19. In the case of Ghana, sustaining such policies could be done by seeking legislation to support them. In the case of the Coronavirus Alleviation Program (CAP), the government could seek legislation to govern the operation and utilization of funds under the program. Post COVID-19, this program could be turned into a pandemic alleviation fund to keep the country prepared at all times. Additionally, the government could have a monitoring and evaluation team to assess the impact of these policies, thus making the necessary adjustments where necessary. This evaluation and monitoring can ensure due diligence and check corrupt practices that have bedeviled many government interventions over time.

Subsequently, both policies require a lot of funds so the availability of funds is very paramount in sustaining them. In the case of Ghana, it is not quite clear as to the availability of adequate funds to sustain such policies over time and as such it is required of the government to seek other forms of financial assistance from the World Bank (WB) and International Monetary Fund (IMF) to support the effective implementation of such policies.

\section{Conclusion}

We recognize the efforts of governments globally in fighting the COVID-19 pandemic. The monetary and fiscal policies are already yielding some positive results on individuals, households, businesses, and the economy at large. These have been very evident in supporting the unemployed, preventing businesses from going bankrupt, and putting the economy back into shape once again. However, these policies are very costly to implement and due to the uncertainties surrounding the COVID-19 pandemic, it has very become crucial as to how long such policies can be sustained as far as this pandemic lag on. From the theoretical views of decision and sustainability theory, we recommend governments and other stakeholders to decide on the appropriate policy that could give the best response and also, is the ability to make sure such policies are maintained over time. Because it is unclear when a vaccine could be ready for global usage or when the pandemic will be over, it is therefore imperative to consider how the fiscal and monetary policies implemented in fighting the COVID-19 
pandemic could be sustained over time. Governments could design appropriate sustainability plans going forward.

\section{Acknowledgements}

The authors gratefully acknowledge the financial support by the Ministry of Education of Humanities and Social Science Grant of China (Grant Number: 17YJC790127), the University of Electronic Science and Technology of China, and the Center for West African Studies, University of Electronic Science and Technology of China. We would like to thank Mr. Roger Arhin and Dr. Lydia Asare-Kyire for providing proofreading support to assist us to complete this work.

\section{Funding}

This work was supported by the Ministry of Education of Humanities and Social Science Grant of China (Grant Number: 17YJC790127), the University of Electronic Science and Technology of China, and the Center for West African Studies, University of Electronic Science and Technology of China.

\section{Author(s)' Contribution}

Elijah Asante Boakye and Zhao Hongjiang: Conceptualization, Methodology, Elijah Asante Boakye and Bright Nana Kwame Ahia: Original Draft, Elijah Asante Boakye, Zhao Hongjiang: Investigation, Bright Nana Kwame Ahia and Millicent Adu Damoah: Writing-Reviewing and editing

\section{Conflicts of Interest}

Authors of this paper declare that we have no competing financial, professional, or personal interests from other parties

\section{References}

Africa CDC (2020). Coronavirus Disease 2019 (COVID-19). https://africacdc.org/covid-19/

African Economic Outlook (2020). Ghana Economic Outlook (May, pp. 1-3). https://au.int/sites/default/files/documents/38116-doc-african_economic_outlook_202 0_.pdf

Alexandria, V. A. A. (2016). 117th Annual Meeting of the American Association of Colleges of Pharmacy, Anaheim, 23-27 July 2016. American Journal of Pharmaceutical Education.

Ayetey, J. S. (2020). COVID-19 Aviation Standstill Hampers Ghana's Development Efforts.

Béland, L.-P., Brodeur, A., \& Wright, T. (2020). The Short-Term Economic Consequences of COVID-19: Exposure to Disease, Remote Work and Government Response. IZA Discussion Paper, 13159, 90.

COVID-19 Statistics (2020). COVID-19 Coronavirus 2019-nCov Statistics Update (Live): 3,121,118 Cases and 216,508 Deaths. https://virusncov.com/ 
Dalton, L., Rapa, E., \& Stein, A. (2020). Protecting the Psychological Health of Children through Effective Communication about COVID-19. The Lancet Child and Adolescent Health, 4, 346-347. https://doi.org/10.1016/S2352-4642(20)30097-3

Delivorias, A., \& Scholz, N. (2020). Economic Impact of Epidemics and Pandemics. European Paliamentary Research Service.

Deloitte Ghana (2020). Economic Impact of the COVID-19 Pandemic on the Economy of Ghana Economic impact of COVID-19 at a Glance.

Deloitte Insights (2020). Banking and Capital Markets: Implications of COVID-19. https://www2.deloitte.com/us/en/insights/economy/covid-19/banking-and-capital-mar kets-impact-covid-19.html

ECA (2020). ECA: The Economic Impact of COVID-19 on African Cities Likely to Be Acute through a Sharp Decline in Productivity, Jobs \& Revenues.

https://www.un.org/africarenewal/news/coronavirus/eca-economic-impact-covid-19-af $\underline{\text { rican-cities-likely-be-acute-through-sharp-decline-productivity }}$

Eggers, W. D., Flynn, M., O’Leary, J., \& Chew, B. (2020). Governments Respond to COVID-19.

https://www2.deloitte.com/us/en/insights/economy/covid-19/governments-respond-to -covid-19.html

Fana, M., Tolan, S., Torrejón, S., Urzi Brancati, C., \& Fernández-Macías, E. (2020). Le misure di confinamento anti Covid e i mercati del lavoro dell ' $U E$. https://doi.org/10.2760/597979

Ghana Investment Promotion Centre (2020). FDI Inflow Begins to Rebound as Ghana Records FDI of 785.62 Million Dollars in First Half of 2020-Ghana Investment Promotion Centre (GIPC).

https://www.gipcghana.com/press-and-media/news-headlines/780-fdi-inflow-begins-to -rebound-as-ghana-records-fdi-of-785-62-million-dollars-in-first-half-of-2020.html

Hossain, N., \& Green, D. (2012). Living on a Spike: How Is the 2011 Food Price Crisis Affecting Poor People? SSRN Electronic Journal. https://doi.org/10.2139/ssrn.2026730

ICAO (2020). Effects of Novel Coronavirus (COVID-19) on Civil Aviation: Economic Impact Analysis.

https://www.icao.int/sustainability/Documents/COVID-19/ICAO_Coronavirus_Econ Impact.pdf

ICNL (2020). African Government Responses to COVID-19.

https://www.icnl.org/post/analysis/african-government-response-to-covid-19

Jiao, W. Y., Wang, L. N., Liu, J., Fang, S. F., Jiao, F. Y., Pettoello-Mantovani, M., \& Somekh, E. (2020). Behavioral and Emotional Disorders in Children during the COVID-19 Epidemic. Journal of Pediatrics, 221, 264-266.e1.

https://doi.org/10.1016/j.jpeds.2020.03.013

John, T. (2020). Iceland Lab Testing Suggests 50\% of Coronavirus Cases Are Asymptomatic.

https://edition.cnn.com/2020/04/01/europe/iceland-testing-coronavirus-intl/index.html

King, R. (2020). CMS to Pay Providers via MIPS for Participating in COVID-19 Drug Treatment Trials.

https://www.fiercehealthcare.com/payer/cms-to-pay-providers-via-mips-for-participati ng-covid-19-drug-treatment-trials

Kostova, D., Cassell, C. H., Redd, J. T., Williams, D. E., Singh, T., Martel, L. D., \& Bunnell, R. E. (2019). Long-Distance Effects of Epidemics: Assessing the Link between the 2014 West Africa Ebola Outbreak and U.S. Exports and Employment. Health Econom - 
ics (United Kingdom), 28, 1248-1261. https://doi.org/10.1002/hec.3938

Lee, J. (2020). Mental Health Effects of School Closures during COVID-19. The Lancet Child and Adolescent Health, 4, 421. https://doi.org/10.1016/S2352-4642(20)30109-7

Ministry of Business Development (2017). Economic Sectors. http://mobd.gov.gh/economic-sectors/

Ministry of Finance (2020). Economic Impact of the COVID-19 Pandemic on the Economy of Ghana.

Nicola, M., Alsafi, Z., Sohrabi, C., Kerwan, A., Al-Jabir, A., Iosifidis, C., Agha, M. and Agha, R. (2020). The Socio-Economic Implications of the Coronavirus Pandemic (COVID-19): A Review. International Journal of Surgery, 78, 185-193.

https://doi.org/10.1016/j.ijsu.2020.04.018

Nikkei Asian Review (2020). South Korea to Pay Families Hundreds of Dollars to Ease Corona Toll.

http://www.usnews.com/news/world/articles/2020-03-29/south-korea-coronavirus-cas es-rise-steadily-more-financial-aid-expected

Nyabor, J. (2020). Coronavirus: Government Bans Religious Activities, Funerals, All Other Public Gatherings.

https://citinewsroom.com/2020/03/government-bans-church-activities-funerals-all-oth er-public-gatherings/

Rossiter, J., \& Abreh, M. K. (2020). COVID-19 Has Forced Exams to Be Suspended across West Africa. Should They Be Overhauled Before They Restart?

https://www.cgdev.org/blog/covid-19-has-forced-exams-be-suspended-across-west-afri ca-should-they-be-overhauled-they

Rummo, P.-E., \& Soosaar, E. (1998). A World. World Literature Today, 72, 330. https://doi.org/10.2307/40153772

S \& P Global (2020). COVID-19 Daily Update. https://www.spglobal.com/en/research-insights/articles/covid-19-daily-update-april-27 $\underline{-2020}$

Santander Group (2020). Foreign Investment in Ghana. https://santandertrade.com/en/portal/establish-overseas/ghana/investing

Schmidhuber, J., Pound, J., \& Qiao, B. (2020). COVID-19: Channels of Transmission to Food and Agriculture.

Schneider, A., \& Domonoske, C. (2020). Oil Prices, Stocks Plunge After Saudi Arabia Stuns World with Massive Discounts: NPR.

https://www.npr.org/2020/03/08/813439501/saudi-arabia-stuns-world-with-massive-di scount-in-oil-sold-to-asia-europe-and-u-

Shereen, M. A., Khan, S., Kazmi, A., Bashir, N., \& Siddique, R. (2020). COVID-19 Infection: Origin, Transmission, and Characteristics of Human Coronaviruses. Journal of Advanced Research, 24, 91-98. https://doi.org/10.1016/j.jare.2020.03.005

Singh, S., Roy, D., Sinha, K., Parveen, S., Sharma, G., \& Joshi, G. (2020). Impact of COVID-19 and Lockdown on Mental Health of Children and Adolescents: A Narrative Review with Recommendations. Psychiatry Research, 293, 113429. https://doi.org/10.1016/j.psychres.2020.113429

Szlezak, P. C., Reeves, M., \& Swartz, P. (2020). Understanding the Economic Shock of Coronavirus. Harvard Business Review.

The Straits Times (2020). Bank of Japan Pumps $\$ 43 b$ in Liquidity, Largest Amount since 2008, Economy News \& Top Stories.

https://www.straitstimes.com/business/economy/bank-of-japan-pumps-43b-in-liquidit 
y-largest-amount-since-2008

The World Bank (2020a). AFRONOMICS: The Economic Impact of COVID-19 (Coronavirus) in Africa.

https://www.worldbank.org/en/news/video/2020/04/13/africas-pulse-the-economic-im pact-of-covid-19-coronavirus-in-africa

The World Bank (2020b). World Bank Group Launches First Operations for COVID-19 (Coronavirus) Emergency Health Support, Strengthening Developing Country Responses.

https://www.worldbank.org/en/news/press-release/2020/04/02/world-bank-group-laun ches-first-operations-for-covid-19-coronavirus-emergency-health-support-strengtheni ng-developing-country-responses

The World Bank (2020c). World Bank Group Supports Ghana's COVID-19 Response. https://www.worldbank.org/en/news/press-release/2020/04/02/world-bank-group-supp orts-ghanas-covid-19-response

The World Bank Group (2020a). Foreign Direct Investment, Net Inflows (BoP, Current US\$)_Ghana.

https://data.worldbank.org/indicator/BX.KLT.DINV.CD.WD?locations=GH

The World Bank Group (2020b). World Development Indicators. https://databank.worldbank.org/reports.aspx?source=2\&series=NE.TRD.GNFS.ZS\#sele ctedDimension_WDI_Ctry

Tobias Buck et al. (2020). Coronavirus Declared a Pandemic as Fears of Economic Crisis Mount. https://www.ft.com/content/d72f1e54-6396-11ea-b3f3-fe4680ea68b5

U.S. Department of Labor (2020). Office of Unemployment Insurance Weekly Claims Report, Employment \& Training Administration (ETA).

Uefa (2020). UEFA EURO 2020. https://www.uefa.com/uefaeuro-2020/

UNESCO (2020). School Closures Caused by Coronavirus (COVID-19). https://en.unesco.org/covid19/educationresponse

United Nations (2020). The Social Impact of COVID-19. https://www.un.org/development/desa/dspd/2020/04/social-impact-of-covid-19/

WHO (2020). Coronavirus (COVID-19) Events as They Happen. Geneva: WHO.

World Bank (2020). COVID-19 (Coronavirus) Drives Sub-Saharan Africa toward First Recession in 25 Years.

Zhong, N. S., Zheng, B. J., Li, Y. M., Poon, L. L. M., Xie, Z. H., Chan, K. H., et al. (2003). Epidemiology and Cause of Severe Acute Respiratory Syndrome (SARS) in Guangdong, People's Republic of China, in February, 2003. The Lancet, 362, 1353-1358. https://doi.org/10.1016/S0140-6736(03)14630-2

Zimmermann, P., \& Curtis, N. (2020). Coronavirus Infections in Children Including COVID-19: An Overview of the Epidemiology, Clinical Features, Diagnosis, Treatment and Prevention Options in Children. The Pediatric Infectious Disease Journal, 39, 355-368. https://doi.org/10.1097/INF.0000000000002660 